\title{
O LONGO E TORTUOSO CAMINHO EM DIREÇÃO À BASE DA PIRÂMIDE
}

\author{
Por Armindo dos Santos de Sousa Teodósio \\ Doutorando em Administração de Empresas pela FGV- EAESP. Professor da PUC Minas \\ E-mail: teodosio@pobox.com
}

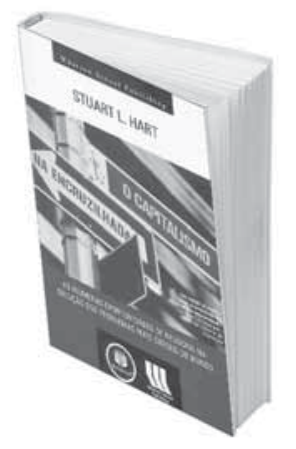

\section{O CAPITALISMO NA ENCRUZILHADA}

De Stuart L. Hart

Porto Alegre: Editora Bookman, 2006, 232 p.
Dizer que responsabilidade socioambiental já se incorporou à agenda das corporações tornou-se lugar-comum. Menos comuns, no entanto, são as tentativas realmente consistentes de construção de estratégias socialmente responsáveis, sobretudo no cenário empresarial brasileiro. Uma das abordagens mais recentes, dentre uma multiplicidade de conceitos e tendências, é a chamada "base da pirâmide", a qual pretende orientar as estratégias empresariais em direção aos milhões de consumidores de baixa renda no planeta.

O livro de Stuart L. Hart, que nos chega em versão brasileira pela Bookman, traz consigo a pretensão de traçar novos rumos para o capital ismo. N essa obra, o autor advoga a tese de que ape- nas por meio de inovação tecnológica radical, gestão ambiental avançada, responsabilidade social, envolvimento profundo na solução dos problemas globais e excelência operacional, as corporações multinacionais conseguirão dar novo fôlego à estrutura econômica capitalista. Para Hart, os desafios provenientes da exclusão social e da degradação ambiental não são problemas apenas de governos e comunidades, mas principalmente do próprio motor do capitalismo contemporâneo: as grandes empresas transnacionais. 0 que está em jogo é a sobrevivência do planeta e das culturas, sem dúvida, mas também a do próprio capitalismo, em sua "encruzil hada de morte".

A publicação tem como grande mérito dotar a discussão sobre a base da pirâmide e sustentabilidade, outro conceito central na obra, de maior consistência teórico-conceitual. De fato, esse conceito também havia sido proposto por C. K. Prahalad em seu A riqueza na base da pirâmide, também publicado em português pela Bookman.

A pesar de compartilharem de pressupostos teóricos semelhantes, Hart foca a discussão ambiental para alcançar a competitividade empresarial, ao passo que Prahalad parece fazer 0 caminho inverso. Essa diferença de enfoque não é meramente estilística e traz desdobramentos decisivos sobre a capacidade analítica dos textos. Além disso, Prahalad analisa alguns casos supostamente bem-sucedidos na base da pirâmide que despertam 
grande questionamento sobre sua efetiva capacidade de promoção da inclusão social e proteção ambiental. A pesar de faltar ao livro de Hart maior diálogo com outras vertentes de estudos socioambientais, seus argumentos conseguem ser mais convincentes quanto à possibilidade de construção de uma sustentabilidade empresarial que seja simultaneamente ambiental e competitiva.

0 mesmo discurso pretensamente avançado pode ser encontrado tanto nas abordagens teóricas e nas estratégias empresariais consistentes de responsabilidade socioambiental quanto nas posturas oportunistas e factuais. Até aqui, nenhuma novidade. Para aqueles que observam com justificada cautela, para não dizer desconfiança, a incorporação da expressão "sustentabilidade" pelo discurso institucional corporativo, o modelo de Hart sobre a base da pirâmide pode ajudar a descortinar uma série de inconsistências dessas estratégias gerenciais.

A sustentabilidade corporativa de Hart exige das empresas a orientação para inovações radicais capazes de subverter trajetórias tecnológicas consolidadas e nichos cômodos de lucratividade. Além disso, segundo o autor, não basta o "esverdeamento" das estratégias empresariais, por meio da adequação às normas e requisitos legais ou voluntários de proteção ambiental, por exemplo. A empresa sustentável é aquela que se vale da inovação tecnológica radical para ir além do que podem e oferecem os sistemas de gestão ambiental.

Como se isso não bastasse, novos desafios se apresentam na conquista dos mercados da base da pirâmide. Para Hart, "tornar-se nativo" é a chave para a sobrevivência competitiva nos mercados de baixa renda. Por sua vez, essa postura exige uma orientação corporativa muito mais efetiva do que simplesmente enviar equipes gerenciais para "passarem al gum tempo" no "exótico" mundo dos pobres, conhecendo seu modo de vida e consumo. Conviver nas comunidades e oferecer soluções competitivas para suas demandas por produtos e serviços implica um profundo respeito pela cultura, tradições e valores dos diferentes grupos que compõem a base da pirâmide nas diferentes regiões do planeta. Contudo, se as idéias de Hart podem se tornar mais uma estratégia pasteurizada e deformada pelas práticas de determinadas corporações, também podem levar a importantes debates em diferentes linhas de investigação no campo da Administração. Um dos caminhos entre as várias triIhas que levam até a base da pirâmide pode ser o profícuo diálogo entre 0 modelo de sustentabilidade proposto por Hart e a chamada "visão baseada em recursos", outro conceito central nas discussões contemporâneas sobre estratégias competitivas.

A RBV, tal qual concebida por J. Barney em artigo no Journal of Management de 1991, assume que a trajetória histórica das empresas, a ambigüidade causal e a complexidade social da inovação são fatores decisivos para a sustentabilidade competitiva das corporações. Além disso, os recursos naturais podem ser assumidos como elementos não imitáveis na competitividade empresarial.

$\mathrm{N}$ ão menos profícua, mas muito mais controversa e instigante parece ser a interlocução da visão de sustentabilidade de Hart com outras correntes bastante sól idas de investigação sobre meio ambiente, tecnologia social e políticas socioambientais construídas ao longo dos anos no Brasil eno mundo. Vários argumentos defendidos por Hart são passíveis de questionamentos decisivos, tais como: o protagonismo das corporações multinacionais na promoção da inclusão social, relegando a um segundo plano a socie- dade civil organizada e os governos; a dificuldade de promover inovações tecnológicas radicais no ambiente empresarial; a idéia de harmonização de conflitos entre comunidades, ONGs e empresas, própria das abordagens de "gestão de stakeholders"; 0 risco de destruição dos saberes e dos negócios tradicionais das pequenas comunidades, além da pirataria biológica e cultural no contato com as grandes corporações; e a interação das multinacionais com governos de países em desenvolvimento pouco transparentes e comprometidos com a igual dade social.

Todos esses aspectos constituem desafios de grande monta para a própria construção sustentável e democrática das comunidades e países. A argumentação de Hart não parece se dar conta disso. Por fim, é preciso refletir sobre as capacidades empresariais para fazer "tudo certo ao mesmo tempo agora" em frentes de atuação tão díspares e complexas, bem como sobre os riscos de se construir uma sociedade na qual o espaço público ambiental cede cada vez mais lugar às relações de mercado, sob a hegemonia de grandes corporações multinacionais.

Pelas próprias controvérsias e possibilidades de investigação que derivam desta obra, ela constitui referência importante para os interessados nos temas da responsabilidade socioambiental e da competitividade empresarial. Talvez a partir dela se perceba que existam muito mais sutilezas entre a abstração das estratégias corporativas e a concretude da base da pirâmide do que possamos inicialmente supor. Talvez seja por isso que Hart recorre a uma canção dos Beatles para intitular um dos capítulos mais importantes de seu livro: The long and wild road to the sustainability ( 0 longo e espinhoso caminho rumo à sustentabilidade). 